\title{
The failure of the United States coercive diplomacy in the era of President Donald Trump: Turkey's persistence in buying S-400
}

\section{Kegagalan diplomasi koersif Amerika Serikat di era Presiden Donald Trump: Kegigihan Turki membeli S-400}

\author{
Febry Triantama*, Cancera Triane Berliana, \& Muhammad Yusril I'za \\ Department of International Relations, Faculty of Philosophy and Civilization, \\ Paramadina University \\ Address: Jalan Gatot Subroto No. Kav. 97, RT.4/RW.4, Mampang Prapatan, South Jakarta, \\ Special Capital Region of Jakarta, Indonesia 12790 \\ Email: febry.triantama408@gmail.com
}

Article History: Received 02 July 2021; Accepted 14 December 2021; Published Online 08 February 2022

\begin{abstract}
Turkey decided to acquire the S-400 air defense system from Russia in 2017. This decision puts Turkey in the shadow of the United States' coercive diplomacy through the CAATSA instrument. However, Turkey showed its persistence, as evidenced by the arrival of the S-400 in Turkey in 2019. This study aims to find out the reason for Turkey's persistence using the concept of coercive diplomacy and descriptive-analytical methods. This article concludes that the reason for Turkey's persistence in buying S-400 was the implementation of United States coercive diplomacy through CAATSA that tends to be "half-hearted". "Half-hearted" coercive diplomacy done by the United States made all three strategies for a successful and effective coercive diplomacy cannot be achieved. First, the demands and threats presented did not have strong credibility and legitimacy. Second, the Turkish government's lack of urgency in complying with the US demands contributed to the cause of such persistence. Finally, the absence of time pressure is also important to assure a successful and effective coercive diplomacy.
\end{abstract}

Keywords: CAATSA; coercive diplomacy; Turkey; S-400

\begin{abstract}
Abstrak
Turki memutuskan untuk mengakuisisi sistem pertahanan udara S-400 dari Rusia pada tahun 2017. Keputusan ini membuat Turki berada dalam bayang-bayang diplomasi koersif Amerika Serikat melalui instrumen CAATSA. Namun, Turki menunjukkan kegigihannya, terbukti dengan kedatangan S-400 di Turki pada tahun 2019. Penelitian ini bertujuan untuk mengetahui alasan di balik kegigihan Turki dengan menggunakan konsep diplomasi koersif dan metode deskriptif-analitis. Artikel ini menyimpulkan bahwa alasan di balik kegigihan Turki membeli S-400 adalah pelaksanaan diplomasi koersif Amerika Serikat melalui CAATSA yang cenderung "setengah hati". Diplomasi koersif "setengah hati" yang dilakukan Amerika Serikat membuat tidak tercapainya ketiga strategi diplomasi koersif secara efektif. Pertama, tuntutan dan ancaman yang diajukan tidak memiliki kredibilitas dan legitimasi yang kuat. Kedua, kurangnya urgensi pemerintah Turki dalam memenuhi tuntutan AS juga menjadi salah satu penyebab kegigihan tersebut. Terakhir, tidak adanya tekanan waktu juga penting untuk memastikan diplomasi koersif dapat berhasil dan terlaksana secara efektif.
\end{abstract}

Kata kunci: CAATSA; diplomasi koersif; Turki; S-400

\section{Introduction}

In the discourse of the study of international relations, especially from neorealism point of view that international system is anarchic, countries will struggle for power and compete with each other. Therefore, the presence of military force in a country becomes essential. It is because, with this military presence, the country can defend itself amid an anarchic international system (Mearsheimer 2001). Through military presence, a country can commit acts of violence - war - against other countries to achieve its national interests (Schelling 1966). The strategy of using violence to achieve a country's national interest is often paired with a diplomacy strategy that is synonymous with peace. 
However, as the times progressed, the country is no longer faced with these two neutral options. It does not always have to choose between using violent or peaceful diplomacy strategies. It is due to the emergence of a new strategy that becomes an alternative, that is using coercive elements or threats (George 1991). This strategy of using coercive elements is known as coercive diplomacy, which was first developed by Thomas Schelling (Schelling 1966). Coercive diplomacy is then increasingly seen in relations between countries, one of which is the United States' relationship with Turkey.

The relationship between the United States and Turkey has been established since the Cold War era. The relationship between the two countries is based on a variety of interests. For example, during the Cold War era, the United States had a great interest in countering the influence of the Soviet Union in Europe and the Middle East, requiring Turkey as part of its alliance (Cakmak \& Güneysu 2013). On the other hand, Turkey also needed protection from the threat posed by the Soviet Union and got economic benefits from American programs such as the Marshall Plan (Keskin-Kozat 2013). Cooperation between the two countries grew closer when Turkey finally joined the North Atlantic Treaty Organization (NATO) (Cakmak \& Güneysu 2013).

However, the close relationship established based on intersecting the interests of the United States and Turkey does not close the possibility of frictions between them. For example, when Iraq War occurred, the Turkish Parliament has made a decision that caused tensions between Ankara and Washington. Turkey chose not to allow the United States to launch a ground attack from Turkey into northern Iraq. It also raises questions about Turkey's strategic partnership with the United States (Arbell 2014). The relationship between the two countries in recent years has been quite dynamic. One that gained the most attention was when Turkey decided to buy a Russian medium-range air defense system, the S-400 (Buhari Gulmez 2020). Turkey's decision to buy the S-400 air defense system from Russia raised new frictions in relations between Ankara and Washington. For some parties, especially the United States and NATO, Turkey's decision was a mistake. NATO viewed Turkey as part of an alliance that is not supposed to acquire weapons systems from a country that was often opposed to NATO. That view is also based on the logic of interoperability within NATO (VOA 2020). Concerns were also often expressed regarding the confidential technology of the F-35 fighter jet developed and operationalized by the United States and other NATO member states (Ali \& Stewart 2019).

Turkey's decision to buy the S-400 from Russia was later attributed to the United States policy, namely Countering America's Adversaries Through Sanctions Act (CAATSA). CAATSA is an instrument of United States coercive diplomacy addressed to countries conducting defense cooperation, including acquiring weapons systems from Russia. Various parties stated that Turkey should be sanctioned following the CAATSA policy. One of the parties pushing President Donald Trump to impose sanctions in line with CAATSA policy was the United States Congress in 2019 (Seligman 2019).

However, the insistence made by various parties did not end in the immediate imposition of CAATSA sanctions by President Trump. Even on one occasion, President Trump declared that the Turkish President was his best friend (Finnegan 2019). However, at the end of his term, President Trump, through Secretary of State Mike Pompeo, formally imposed CAATSA sanctions on Turkey on December 14, 2020 (Zanotti $\&$ Thomas 2020). It indicates that the CAATSA sanction was only imposed 1.5 years after Turkey made the acquisition (Finnegan 2020).

Turkey did not heed concern, denial, and threat coming from the United States and NATO. On several occasions, Turkish President Recep Tayyip Erdogan rejected the Turkish alliance's request to cancel the planned purchase of the S-400. Turkey considered the decision to be Turkey's sovereign right to realize the security of the country. Moreover, Turkey also stated that the decision to buy the S- 400 was also due to the United States' slowness in response to Turkey's desire to purchase a similar air defense system developed by the United States. Turkey's persistence in acquiring the S-400 amid threats until the imposition of the CAATSA sanctions is very interesting to research. Why does Turkey, as part of 
the United States and NATO alliance that already committed to staying away from Russian technology, seem to ignore the United States' coercive diplomacy through CAATSA sanctions?

Reflecting on the empirical facts of bilateral relations between the United States and Turkey that have long been established, several studies have discussed the relationship between the two countries. Studies examining the relationship between the United States and Turkey can be categorized into three categories: (1) Foreign Policy, (2) Security, and (3) Argumentative Papers.

Research belonging to the foreign policy category, in general, illustrates how the relationship between the United States and Turkey formed. The dynamic between the relationship of the United States and Turkey is undoubtedly a result of each country's foreign policy (Altunişik 2013, Sayari 2013, Martin 2019). The foreign policy that led to the turmoil of the relationship between the two alliance countries is inseparable from the dynamic national interest (Criss 2013, Cakmak \& Güneysu 2013).

Previous studies have also covered the security category, looking at the security field of the United States and Turkey where the two countries have a strategic partnership (Müftüler-Bac 2006). However, the policies imposed by each country are carried out to protect each country's interests and positions, just as Turkey implemented the Fear of Entrapment policy (Buhari Gulmez 2020). Also, the volatile Middle East created a Bipolarizing System between Iran and the United States that could affect the relationship between the United States and Turkey (Martin 2019). As mentioned above, previous research about the United States and Turkey bilateral relations has also been widely conducted. The studies included in the third category are research in the form of argumentative papers, explaining that the dynamics of Ankara and Washington relationship are inseparable from each country's interest and their common interest, ranging from economics, politics, and strategics (Menon \& Wimbush 2007, Türkmen 2009, Cook 2011).

Based on the previous research, it can be concluded that several factors trigger bilateral relations between Turkey and the United States; one of them is a mutual interest, which fosters cooperation and results in policies developed by each country. However, of all the studies conducted, the research that discusses the sanctions imposed by the United States against Turkey based on violations of the policy of Countering America's Adversaries Through Sanctions Act (CAATSA) as a result of the purchase of the S-400 air defense system from Russia remains extremely limited. The fact is that Turkey is part of a NATO member and part of the F-35 Joint Strike Fighters Program run by the United States. However, on the other hand, Turkey agreed with Russia in the purchase of the S-400 system, which has violated CAATSA and at the same time caused confusion over Turkey's actions and anxiety within NATO. Because Turkey's decision was not in line with Turkey's supposed position as United States strategic partners and NATO members that are committed to staying away from Russian technology, it needs further research on why Turkey bought the S-400 from Russia. In addition, until the arrival of the S-400 system, the United States has not imposed any concrete sanctions on Turkey; although the United States has removed Turkey from F-35 participation, real sanctions in the form of embargoes or other forms have not been imposed on Turkey as it should have been due to CAATSA violations.

According to Alexander George, coercive diplomacy is an act of state to do coercion, such as blackmailing other countries to force them to do something and using threats, bargaining, and negotiations to force them to stop doing something (George 1991). Coercive diplomacy, according to George, has three variables. The first is clear demand against other countries. The sender country gives this demand to the target country of coercive diplomacy. The demand given must be clear and have good credibility legitimacy to be met by the target country (George 1991). Tom Sauer claims that the demand becomes legitimized if it is in line with international law (Sauer 2007). Meanwhile, related to the threat's credibility, Sauer said that the demand or request should apply uniformly to other countries (Sauer 2007). In other words, there should be no double standard in giving the demand or request. Suppose the request or demand provided is not legitimized and not credible. In that case, the probability of the demand followed by the target country becomes low. 
The second variable in the concept of coercive diplomacy is the threat. A threat must accompany a request or demand by the sender state. It is intended to encourage target countries to be more compelled to meet the sender state's demand (George 1991). However, it does not mean that coercive diplomacy will surely succeed with the sender state's threat. In line with the variable demand, the threat given must have credibility. The threat's credibility can be seen from whether the threat matches the demand and the sender state's reputation in conducting similar coercive diplomacy before.

Third, there is a time limit or urgency in meeting the demands. In order for coercive diplomacy that has a high probability of succeeding, the sender state needs to create urgency for the target country (George 1991). The target country's urgency to comply with coercive diplomacy arises if the given deadline is clear and not too loose or too soon (George 1991).

By presenting the definition and concept of coercive diplomacy by George, it can be concluded that coercive diplomacy is one part of strategic diplomacy that becomes the driving instrument in achieving a country's wants and objectives. Coercive diplomacy is also inseparable from threats and coercion in its implementation process. Therefore, based on the case of the research raised, this study used a combination of the three variables. Using coercive diplomacy as the theoretical background, this article wants to explain why United States' coercive diplomacy through the Countering America's Adversaries Through Sanctions Act (CAATSA) to Turkey fails.

\section{Research Method}

This research was conducted by using a qualitative approach. According to Christopher Lamont (2015), qualitative research is based on strategies or techniques for collecting and analyzing data that are nonnumeric or based on the use of words (Lamont 2015). This research used both primary and secondary data. Primary data were obtained from documents issued by the government and official information and statement released by the government through press releases or official websites of the government/ related ministries, etc. Documents refer to text or anything that is written, visually visible, or spoken through the medium of communication (Neuman 2004). Secondary data is obtained from literature review, printed and online mass media, and previous research published in reputable journals and other scientific reports. Data analysis was carried out by using triangulation techniques to clarify and crosscheck the data obtained on the research variables and indicators. Furthermore, the authors described the causal mechanism between variables so that the research questions can be addressed scientifically.

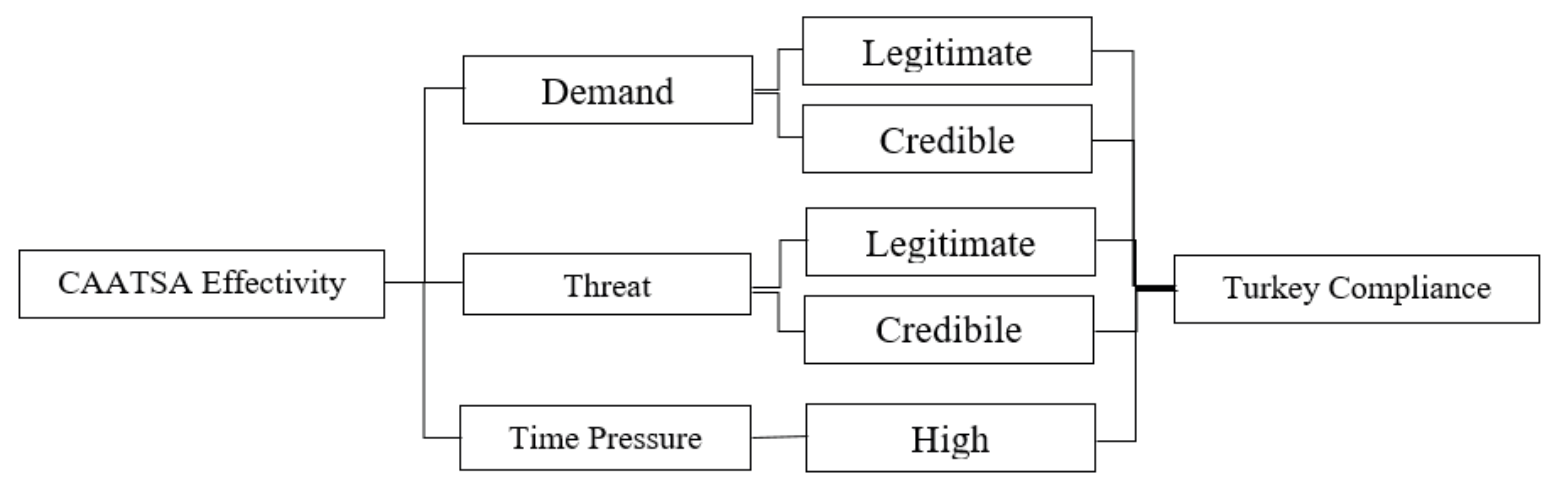

Figure 1.

Analytical model

Source: George (1991), Sauer (2007)

Figure 1 explains that Turkey's compliance with the United States' coercive diplomacy through CAATSA depends on how the United States implements its coercive diplomacy. Three variables determine the success and effectiveness of coercive diplomacy. First, this research will look at two indicators in the demand variable, which is whether the United States' demand has legitimacy and credibility. The second 
variable is the threat; similar to the demand variable, the variable of the United States' threat to Turkey for its legitimacy and credibility. The last variable is time pressure; in this variable, it will be seen whether the United States puts a strict and firm time pressure on Turkey to meet the demands.

\section{Results and Discussion}

\section{United States's demand within CAATSA framework: Illegitimate and lack of credibilities}

It is necessary to understand the philosophical basis behind CAATSA to understand the United States' request within the framework of CAATSA easily. The philosophy of CAATSA can be seen by referring to the speech delivered by Dr. Christopher Ashley Ford - an official at the United States Bureau of International Security and Non-Proliferation before the Senate. At that time, it was conveyed that the philosophy of CAATSA formulation was to confront and counter Russia's influence in the defense sector (US Department of State 2017). The United States government views Russia as a revisionist power and utilizes defense cooperation and arms sales as a means of gaining influence (US Department of State 2017). It is seen as a threat to the security of the United States and its alliance countries (Zanotti \& Thomas 2020). Because of this philosophical basis, the United States' request within the framework of CAATSA became clear. The United States asks countries around the world not to make arms purchase transactions from Russia. It is because the United States believes Russia used arms sales to acquire and strengthen its influence.

In the context of the United States' request to Turkey, the United States initially asked Turkey to cancel its planned acquisition of the Russian S-400 air defense system. The United States officials repeatedly submitted this request. For example, when the United States Acting Secretary of Defense Mark Esper met NATO defense ministers (DW 2019a). At that time, Esper stated that if Turkey continued its plan to acquire the S-400, it would severely damage the good relations established for a long time (DW 2019b). Another request was done by the United States acting Secretary of Defense, Patrick Shanahan, who has also voiced the United States' demand to Turkey to cancel its planned acquisition of the S-400 (DW 2019b).

The Turkish government did not heed the United States government's demand for Turkey to cancel its plans to acquire the S-400. President Erdogan and the government officials have said that an agreement with Russia has been reached. The agreement that has been reached was said to be impossible to cancel. If looking at President Erdogan and the government officials' statements, there are at least two reasons why it is impossible to cancel the planned acquisition. First, President Erdogan stated that in September 2017, Turkey had made a first-stage payment to Russia regarding the acquisition of the S-400 (Unal 2017). Second, the purchase of the S-400 is part of Turkey's efforts to maintain sovereignty and create independence (Mohammed \& Pamuk 2021).

Based on the narratives conveyed by Ankara regarding its refusal to follow Washington's wishes which are an inseparable part of coercive diplomacy, it can be found that one of Ankara's reasons is sovereignty and independence. The pretext of maintaining the sovereignty and independence of the state is indeed a very reasonable reason in international politics. There are at least two theories in the study of international relations that can serve as a basis for justifying this narrative. First, referring to one of the major paradigms of the study of International Relations, namely neorealism, every country in the international system will try to maintain its survivability and sovereignty. Kenneth Waltz stated that in order to maintain survivability and sovereignty, a state would act as an actor by maximizing powers, such as through the acquisition of weapons technology (Waltz 1979). Using the arguments put forward by neorealism and Waltz, the narrative of Turkey insisting on acquiring the S-400 is a very understandable one.

Second, in an effort to increase countries' power capacity by acquiring imported weapons systems, according to some experts, they can actually jeopardize the security and independence of the state. This 
is because countries that are too dependent on weapons systems produced by other countries have the potential to be trapped in the influence of arms producers (Krause 1991, Neuman 2010, Bitzinger 2017). Arms producers countries often take advantage of their status to achieve national interests and certain motives for their interest. Countries will do counter-dependent measures to prevent this from happening, which can be done through two strategies: diversification of weapons supplying countries and developing domestic defense industry. Efforts against this dependence are done by Turkey, including in the context of the acquisition of the S-400. Through the acquisition of the S-400 from Russia, Turkey, which is a NATO member country, where most of its weapon systems come from the NATO bloc, automatically diversifies the weapons supplying countries. When diversification of weapons, such as through the acquisition of the S-400, is successfully carried out, the dependence and influence of the United States are also decreasing. In other words, Turkey is increasingly gaining independence or freedom in its foreign policy.

Seeing the Turkish government not following the demands submitted earlier, the United States government changed the demand. While previously the United States government demanded Turkey to cancel the planned acquisition, before the arrival of the S-400 to Turkey, the United States later demanded that Turkey not operationalize it. This change was seen through the United States government's demand to Turkey through Secretary of State Mike Pompeo's statement in July 2019. At the time Mike Pompeo stated that the United States wanted Turkey to not operationalize the S-400 (Cirilli \& Wadhams 2019). However, this claim was again rejected by Turkey (Gumrukcu \& Coskum 2020).

Even after the long "delayed" CAATSA sanctions imposed by Washington, Ankara stands still on its decision. In a statement issued by the Turkish Ministry of National Defense on December 15, 2020, regarding the CAATSA sanctions applied by Washington, Ankara said that all of Washington demands lack legitimacy and credibility:

\begin{abstract}
"Our allies were notified that the S-400 would not be integrated with the NATO systems or the national systems connected with the NATO systems and that they would be used as the systems with Russian origin in other NATO countries. Our proposal for negotiating the interaction of S-400s and F-35s in a workgroup also with the involvement of NATO still stands. Imposing sanctions instead of discussing a solution to the problem is a step towards a deadlock." (Sunnetci 2020)
\end{abstract}

Three days after releasing the Ministry of National Defense official statements, Hulusi Akar (Turkish Minister of National Defense) in his interview with a journalist said that Turkey is standing at a correct point. He said that Ankara did not purchase the S-400 systems discreetly, and it was the result of the rejection from Washington on Ankara's proposals for acquisitions of the Patriots air defense system.

"We are standing at a correct point. We did not purchase the S-400 systems discreetly, we requested Patriots. The Patriot batteries from NATO arrived and went back. We need to protect a population of 83 million people. There is a wide variety in respect to the F35s. We perceive developments through global thinking. All options are laid on the table." (Sunnetci 2020)

Turkey's persistence in buying the S-400 despite the United States' demand can be explained using the concept of coercive diplomacy. As it is known, the demand given must gain legitimacy so that it can be accepted by the target country. According to Sauer, the legitimacy of the demand can be obtained if the demand is in accordance with mutually recognized international law and the uniformity of the demand against other countries. In the context of the CAATSA, the Turkish government considered the demand provided by the United States did not have legitimacy. Indeed, the CAATSA is known as a policy made by the United States, not international law. Also, the differences in treatment towards other countries resulted in the legitimacy of the United States' demand against Turkey low. This different treatment can be seen when the United States decided to grant a CAATSA waiver against India, which also acquired the S-400 (Prastiti 2019). 
In addition to these two aspects that weaken the legitimacy of the United States' demand against Turkey, there are other aspects that undermine the demand's legitimacy. That is a reluctance to impose CAATSA sanctions, as seen from President Trump's figure. The bilateral meeting between President Trump and President Erdogan on the sidelines of the G20 summit in Osaka in 2019 is evidence of President Trump's reluctance to impose CAATSA sanctions immediately. When asked by journalists after the bilateral meeting, President Trump explicitly stated that he would seek other solutions to resolve the issue (Aliriza 2019).

Furthermore, the reluctance to impose CAATSA sanctions is also seen when President Trump did not heed the urging of members of the United States Congress. On numerous occasions, members of the United States Congress from both Democrats and Republicans, have voiced their demands for President Trump to impose CAATSA sanctions on Turkey. However, again President Trump has not imposed the CAATSA sanctions until the very end of his presidency. There were even rumors that the Secretary of State and The United States National Security Adviser were prepared to impose CAATSA sanctions, but President Trump himself thwarted the plan (Liptak \& Gaouette 2019).

\section{United States threat: Same problems occurs}

Coercive diplomacy as a state strategy to achieve its national interests cannot be separated from the threat aspect. The threat is also an element that differentiates coercive diplomacy from "normal diplomacy". According to George and Sauer's explanation, in carrying out coercive diplomacy, the demands given in addition to having legitimacy must also be followed by threats. In the context of this study, CAATSArelated threats have been listed in the CAATSA rules themselves.

CAATSA, signed in August 2017, has listed various types of sanctions threats that can be given. There are at least twelve types of sanctions that can be imposed on Turkey based on CAATSA, including: (1) Sanction U.S. Export-Import Bank credit or assistance, (2) Sanction U.S. exports of goods and services, (3) Sanction large loans from U.S. financial institutions, (4) Seek to block loans from international financial institutions including the World Bank and International Monetary Fund, (5) Sanctions on financial institutions holding U.S. government funds or serving as U.S. primary dealer, (6) Sanction U.S. procurement of goods or services, (7) Sanction any foreign-exchange transactions under U.S. jurisdiction, (8) Sanction any bank payments or transfers subject to U.S. jurisdiction, (9) Sanction any transactions related to property, (10) Sanction any investment in U.S. debt or equity, (11) Deny visas to corporate officers related to sanctioned entity or person, (12) Sanctions on principal executive officers of targeted entity or person (US Department of State 2017). Based on CAATSA's legal documents, the President of the United States is obligated to impose at least 5 kinds of sanctions out of a total of 12 possible sanctions.

However, the threats to impose CAATSA sanctions on Turkey, as mentioned earlier, lack credibility. For example, the statement of United States officials that they will not grant waivers to any country related to CAATSA is not in accordance with the reality. The United States instead granted waivers to countries like India (Prastiti 2019) and considered giving the same to Vietnam and Indonesia (Defenseworld.net 2018).

This is in line with the weak legitimacy of the United States' demand because it is influenced by United States domestic politics and is not supported by international law. The credibility of the threat is also affected by Washington's domestic political dynamics. As Prastiti said in her article (2019), the United States Department of State officials had threatened by saying, "There are no blanket waivers that will be issued for any one country." In other words, the United States insists that CAATSA will be applied universally to all violators without exception. This, however, turned out to be the exact opposite; even though it had threatened to impose sanctions through its law - Countering America's Adversaries Through Sanctions Act (CAATSA) - the United States did not dare to prove its threat to Turkey firmly (Prastiti 2019). Moreover, the United States government appears to be split over the possibility of CAATSA 
sanctions being imposed on Turkey. Secretary of State Mike Pompeo has expressed confidence that President Trump will comply with the rules and impose CAATSA sanctions (Joung 2019). However, at a close time, a senior official in the Trump administration said the contrary. Even President Trump instead appointed Senator Lindsey Graham to speak with the Turkish government instead of asking Mike Pompeo (Joung 2019).

Senator Lindsey Graham later conveyed a statement opposing Mike Pompeo. He stated that although Turkey continues to buy the S-400, none of the CAATSA sanctions should be imposed as long as the S-400 is not operationalized (Joung 2019). It is not only contrary to Mike Pompeo's previous statements but also contrary to CAATSA itself. Under its rules, CAATSA sanctions will be imposed on countries that make weapons purchases with Russia. Senator Lindsey Graham's statement seemed to have no problem with Turkey's purchase transaction of Russian weapons.

On the Turkish side, President Erdogan made a statement about his confidence that President Trump would not impose CAATSA sanctions on Turkey. President Erdogan believes that his good personal relations with President Trump are one of the reasons why the imposition of CAATSA sanctions is not imaginable:

"For America to get up and confront Turkey with a matter like CAATSA is disrespectful to a very important NATO partner. I do not know where this will lead to before Trump leaves but during the four-year Trump period, I didn't have any problems in communicating with America." (Altan 2020)

Turkish Vice President Fuat Oktay also shared his thoughts on the United States' coercive diplomacy through CAATSA as an unacceptable alliance gesture. Even after the United States finally imposed the sanctions in December 2020, he said, "The decision of the US on the imposition of sanctions will only increase our determined steps taken to forward our national interests and the defense industry under the leadership of our President. Turkey's proud stance will not be affected by the sanctions of any country. We condemn the US resolution and invite them to correct this mistake." In his statement, Mevlüt Cavusoglu (Turkish Minister of Foreign Affairs) said that Ankara declined the imposition of CAATSA sanctions by the United States and said that Turkey would stand tall with pride (Sunnetci 2020). All of these statements reflect that Ankara did not perceive its NATO alliance threat through CAATSA as a legitimate threat. Ankara stands with its decision to buy the S-400 air defense system as its national security interest. No one, even Washington, can dictate.

Ankara's narrative, when it rejected and even condemned the CAATSA sanctions that Washington finally imposed, did not explicitly mention sovereignty, but instead used a national interest narratives. Although not explicitly stated, the factor of sovereignty or survivability also remains the basis of Turkey's attitude and narrative. In neorealism, the ultimate national interest of every nation is to maintain its sovereignty and survivability (Waltz 1979, Mearsheimer 2001). The narrative of Turkey's counter-dependent efforts through the development of the domestic defense industry is also reiterated. Referring to Turkish Vice President Fuad Oktay's statement that CAATSA will only strengthen Turkey's ambitions and efforts to develop a domestic defense industry, Turkey's policy that seems to be at odds with the United States can facilitate weapons development cooperation with Russia. Even today, Ankara has openly expressed its desire to strengthen cooperation with Russia, including in the development of weapons (Mohammed \& Pamuk 2021).

\section{United States reluctancy to immediately impose CAATSA sanctions}

Since several years ago, Turkey's decision to acquire the S-400 medium-range air defense system from Russia had been decided. The acquisition process began after the Turkish government negotiated with Russia in 2016 (Karako 2019, Macias 2020). The negotiation process lasted for approximately one year. In 2017, the President of Turkey announced that an agreement had been reached with Russia regarding 
the acquisition of the S-400 air defense system. The counter-acquisition is reported to reach US\$2.5 billion (Karako 2019, Macias 2020).

As mentioned earlier, after the deal in 2017, criticism and demands for Turkey to cancel the acquisition process emerged. However, Turkey remained steadfast in its decision to acquire the S-400. Turkey's unwavering response to requests, demands, and threats posed by the United States was evident when in July 2019, the first shipment of S-400 arrived in Turkey (Karako 2019). President Donald Trump recently imposed CAATSA sanctions on Turkey on December 14, 2020. In other words, CAATSA sanctions were only imposed three years after the deal was established and 1.5 years after the S- 400 was received by Turkey.

In accordance with the third variable concept of coercive diplomacy, which is deadlines as a suppressor, Turkey is not related to a clear deadline. Based on the timeline of Turkey's acquisition of the S-400 agreed in 2017, President Donald Trump did not immediately impose CAATSA sanctions. President Donald Trump and members of his cabinet seemed reluctant to impose sanctions on Turkey immediately.

President Donald Trump and his cabinet's reluctance to immediately impose CAATSA sanctions and instead seem to protect Turkey can be seen on numerous occasions. For example, President Trump's statement at his cabinet meeting in 2018; at that time, President Trump blamed the previous United States government under Barack Obama's leadership instead (Liptak \& Gaouette 2019). On the same occasion, President Trump also stated that President Erdogan was forced to acquire the S-400 because Turkey was in difficult conditions. President Trump made no mention at all about the timing of CAATSA sanctions on Turkey (Liptak \& Gaouette 2019).

Referring to the concept of coercive diplomacy mentioned above, the success of coercive diplomacy is also determined by clear and not very loose deadlines. Therefore, in the case of coercive diplomacy through CAATSA, success is also determined by the emergence of a sense of urgency on the Turkish side from the deadline given by the United States. However, in reality, President Donald Trump seemed reluctant to impose CAATSA sanctions immediately on Turkey, and there was never a clear deadline. Even after Turkey received the S-400 from Russia in mid-2019, President Trump's government has not imposed sanctions. The insistence of the United States Congress since 2018 did not make Trump immediately impose CAATSA sanctions. It is why Turkey does not feel the need to cancel its plans to acquire the S- 400 .

\section{Conclusion}

Turkey, in 2017, reached an agreement to buy the S-400 air defense system from Russia. This decision also opened the chance of CAATSA sanctions imposed by the United States as a form of coercive diplomacy. However, despite being in the shadow of CAATSA sanctions, the Turkish government showed its persistence in acquiring the S-400. The persistence shown by Turkey is based on the implementation of coercive diplomacy through CAATSA, which seems half-hearted. Although the United States has expressed its demands and threats against Turkey on numerous occasions, the doubt or reluctance of President Donald Trump to impose sanctions under CAATSA rules that he signed himself is still obvious.

Furthermore, the threat that can be imposed through CAATSA is not supported by international law. Ankara believes that the demands posed by Washington are weak in legitimacy and credibility, so Ankara does not have to cancel its plan on buying the S-400 air defense system. Also, coercive diplomacy through CAATSA does not cause a sense of urgency on the Turkish side due to the unclear deadline given by the United States for Turkey to comply with its demand. 


\section{Reference}

Ali I \& Stewart P (2019) U.S. removing Turkey from F-35 program after its Russian missile defense purchase. Reuters, 18 July. [Accessed 10 December 2021]. https:/www.reuters.com/article/usturkey-security-usa-idUSKCN1UC2DD.

Altan A (2020) Turkey's Erdogan blasts 'disrespectful' US sanctions plan. Al-Monitor, 11 December. [Accessed 03 February 2021]. https://www.al-monitor.com/originals/2020/12/erdogandisrespectful-caatsa-sanctions-trump-biden-eu.html.

Aliriza B (2019) Trump-Erdogan Meeting at the G20: End of the S-400 Crisis? CSIS, 03 July. [Accessed 21 July 2020]. https://www.csis.org/analysis/trump-erdogan-meeting-g20-end-s-400-crisis.

Altunişik MB (2013) The Middle East in Turkey-USA relations: Managing the alliance. Journal of Balkan and Near Eastern Studies 15 (2):157-173. https://doi.org/10.1080/19448953.2013.775036.

Arbell D (2014) The U.S.-Turkey-Israel Triangle. Washington DC: The Brookings Institution.

Bitzinger RA (2017) Asian arms industries and impact on military capabilities. Defence Studies 17 (3):295-311. https://doi.org/10.1080/14702436.2017.1347871.

Buhari Gulmez D (2020) The resilience of the US-Turkey alliance: Divergent threat perceptions and worldviews. Contemporary Politics 1-18. https://doi.org/10.1080/13569775.2020.1777038.

Cakmak C \& Güneysu G (2013) Turkish-American relations during Obama era: Unfulfilled expectations. Turkish Studies 14 (2):193-211. https://doi.org/10.1080/14683849.2013.802923.

Cirilli K \& Wadhams N (2019) Pompeo urges Turkey not to make Russian S-400 ‘operational.’Bloomberg News. [Accessed 21 July 2020]. https://www.bloomberg.com/news/articles/2019-07-25/pompeourges-turkey-not-to-make-russian-s-400-operational.

Cook SA (2011) The USA, Turkey, and the Middle East: Continuities, challenges, and opportunities. Turkish Studies 12 (4):717-726. https://doi.org/10.1080/14683849.2011.622510.

Criss NB (2013) The USA-Turkey-Middle East: From the 20th century to the present. Journal of Balkan and Near Eastern Studies 15 (2):143-156. https://doi.org/10.1080/19448953.2013.775023.

Defenseworld.net (2018) US to exempt India, Indonesia and Vietnam from CAATSA sanctions. Defenseworld.net, 24 July. [Accessed 21 July 2020]. https://www.defenseworld.net/news/23031/ US_to_Exempt_India_Indonesia_and_Vietnam_from_CAATSA_Sanctions\#.YAZal-gzZPZ.

DW (2019a) US threatens Turkey with sanctions over S-400 deal. DW, 27 June. [Accessed 21 July 2020]. https://www.dw.com/en/us-threatens-turkey-with-sanctions-over-s-400-deal/a-49369721.

DW (2019b) Turkey confirms Russia S-400 missile deal, ignores US warning. DW, 12 June. [Accessed 21 July 2020]. https://www.dw.com/en/turkey-confirms-russia-s-400-missile-deal-ignores-uswarning/a-49168150.

Finnegan C (2019) Trump to welcome Erdogan as friend despite high tensions in US-Turkish relations, bipartisan condemnation of Turkey. ABC News, 13 November. [Accessed 21 July 2020]. https://abcnews.go.com/Politics/trump-erdogan-friend-high-tensions-us-turkish-relations/ story?id $=66917017$.

Finnegan C (2020) US sanctions NATO ally Turkey for purchasing Russian missile system. ABC News, 15 December. [Accessed 21 July 2020]. https://abcnews.go.com/Politics/us-sanctions-turkeypurchasing-russian-missile-system/story?id $=74672022$.

George A (1991) Forceful Persuasion: Coercive Diplomacy as an Alternative to War. Washington DC: United States Institute of Peace.

Gumrukcu T \& Coskun O (2020) Turkey says U.S. offering Patriot missiles if S-400 not operated. Reuters, 10 March. [Accessed 10 September 2021]. https://www.reuters.com/article/us-turkeysecurity-usa-idUSKBN20X1I8.

Joung M (2019) How President Trump is undercutting Pompeo in a dispute over Turkey's purchase of a Russian missile system. Time, 02 August. [Accessed 21 July]. https://time.com/5633196/trumppompeo-turkey-sanctions-russia-s400/.

Keskin-Kozat B (2013) Negotiating an Institutional Framework for Turkey's Marshall Plan: The Conditions and Limits of Power Inequalities. In: Örnek C. \& Üngör Ç. (eds). Turkey in the Cold War. London: Palgrave Macmillan. https://doi.org/10.1057/9781137326690_10. 
Karako T (2019) Coup-proofing? Making sense of Turkey's S-400 decision. CSIS, 15 July. [Accessed 21 July 2020]. https://www.csis.org/analysis/coup-proofing-making-sense-turkeys-s-400-decision.

Krause K (1991) Military statecraft: Power and influence in Soviet and American arms transfer relationships. International Studies Quarterly 35 (3):313-336. https://doi.org/10.2307/2600702.

Lamont C (2015) Research Methods in Politics and International Relations. New York: Sage Publications. Liptak K \& Gaouette N (2019) Trump blames Obama as he reluctantly bans F-35 sales to Turkey. CNN Politics, 17 July. [Accessed 21 July 2020]. https://edition.cnn.com/2019/07/16/politics/trumpturkey-s400-sales/index.html.

Macias A (2020) U.S. sanctions Turkey over purchase of Russian S-400 missile system. CNBC, 14 December. [Accessed 21 July 2021]. https://www.cnbc.com/2020/12/14/us-sanctions-turkeyover-russian-s400.html.

Martin LG (2019) Analysing a tumultuous relationship: Turkey and the US in the Middle East. Asian Journal of Middle Eastern and Islamic Studies 13 (2):1-16. https://doi.org/10.1080/25765949.20 19.1605571.

Mearsheimer JJ (2001) The Tragedy of Great Power Politics. New York: W.W. Norton \& Company.

Menon R \& Wimbush SE (2007) The US and Turkey: End of an alliance? Survival 49 (2):129-144. https://doi.org/10.1080/00396330701437785.

Mohammed A \& Pamuk H (2021) U.S. secretary of state nominee Blinken says Turkey not acting like an ally. Reuters, 20 January. [Accessed 10 September 2021]. https://www.reuters.com/article/us-usabiden-state-turkey/us-secretary-of-state-nominee-calls-nato-ally-turkey-a-so-called-strategicpartner-idUSKBN29O2OM.

Müftüler-Bac M (2006) Turkey and the United States: The impact of the war in Iraq. International Journal 61 (1):61-81. https://doi.org/10.1177/002070200606100104.

Neuman SG (2010) Power, influence, and hierarchy: Defense industries in a unipolar world. Defence and Peace Economics 21 (1):105-134. https://doi.org/10.1080/10242690903105398.

Neuman WL (2004) Basics of Social Research: Qualitative and Quantitative Approaches. London: Pearson.

Prastiti DNB (2019) Countering America's Adversaries Through Sanctions Act (CAATSA) inconsistencies: The case of India S-400 weapon procurement. Jurnal Global \& Strategis 13 (2):123-139. https://doi.org/10.20473/jgs.13.2.2019.123-139.

Sauer T (2007) Coercive diplomacy by the EU: The Iranian nuclear weapons crisis. Third World Quarterly 28 (3):613-633. https://doi.org/10.1080/01436590701200620.

Sayari S (2013) New directions in Turkey-USA relations. Journal of Balkan and Near Eastern Studies 15 (2):129-142. https://doi.org/10.1080/19448953.2013.775022.

Schelling T (1966) Arms and Influence. New Haven: Yale University Press.

Seligman L (2019) U.S. lawmakers move to punish Turkey for buying Russian missile system. Foreign Policy, 10 December. [Accessed 21 July 2020]. https://foreignpolicy.com/2019/12/10/uslawmakers-move-punish-turkey-buying-russian-missile-system-s400/.

Sunnetci I (2020) Turkey's CAATSA reactions \& statements. Defence Turkey. [Accessed 21 July 2021]. https://www.defenceturkey.com/en/content/turkey-s-caatsa-reactions-statements-4384.

Türkmen F (2009) Turkish-American relations: A challenging transition. Turkish Studies 10 (1):109129. https://doi.org/10.1080/14683840802648729.

Unal A (2017) Erdoğan: S-400 is a done deal, down payment already transferred to Moscow. Daily Sabah, 12 September. [Accessed 10 December 2021]. https://www.dailysabah.com/diplomacy/2017/09/12/ erdogan-s-400-is-a-done-deal-down-payment-already-transferred-to-moscow.

US Department of State (2017) Section 231 of the countering America's adversaries through sanctions Act of 2017. [Accessed 15 March 2019]. https://www.state.gov/countering-americas-adversariesthrough-sanctions-act-of-2017/sections-231-and-235/.

Waltz KN (1979) Theory of International Politics. Boston: Addison-Wesley Publishing Company.

Zanotti J \& Thomas C (2020) Turkey: U.S. sanctions under the Countering America's Adversaries Through Sanctions Act (CAATSA). Congressional Research Service, 16 December. [Accessed 21 July 2021]. https://sgp.fas.org/crs/mideast/IN11557.pdf. 